Egyptian Journal of Aquatic Biology \& Fisheries

Zoology Department, Faculty of Science,

Ain Shams University, Cairo, Egypt.

ISSN $1110-6131$

Vol. 25(4): $241-252$ (2021)

www.ejabf.journals.ekb.eg

\title{
Age, growth and mortality of the Bartail Flathead (Platycephalus indicus) in Bardawil lagoon, North Sinai, Egypt.
}

\author{
Kassem S. Ahmed ${ }^{1}$, Hasanen G. D. ${ }^{2}$, Salem M. A. ${ }^{2}$, Mousa M. A. ${ }^{1}$ \\ ${ }^{1}$ Center Laboratory for Aquaculture Research (CLAR), Egypt \\ ${ }^{2}$ Al-Arish University, Egypt \\ Corresponding Author: samahkassem23992@gmail.com
}

\begin{abstract}
ARTICLE INFO
Article History:

Received: July 13, 2021

Accepted: July 29, 2021

Online: Aug. 6, 2021

Keywords:

Age,

growth,

mortality,

Platycephalus indicus,

Bardawil lagoon,

Egypt.

\section{ABSTRACT}

Age, growth, and mortality of bartail flathead (Platycephalus indicus) were studied from a small scale fishery of Bardawil lagoon, North Sinai, Egypt. A total of 947 specimens of Platycephalus indicus varied from 17.9 to $52.1 \mathrm{~cm}$ TL with weights ranging between 27.6 and $1003.7 \mathrm{~g}$ were collected from August to December during two fishing seasons 2019-2020. A subsample of 654 specimens was taken for age determination using otoliths readings. The relationship between length and weight was $\mathrm{W}=$ $0.002 \mathrm{~L}^{3.3402}\left(\mathrm{R}^{2}=0.98\right)$ indicating a positive allometric growth. Age was determined and age groups 0 to 5 years were observed. Growth in length and weight at the end of each year of life were calculated. The growth parameters of von Bertalanffy equation was calculated as $\mathrm{L}_{\infty}=59.98 \mathrm{~cm}$ $\mathrm{TL}, \mathrm{K}=0.34 \mathrm{yr}^{-1}, \mathrm{t}_{0}=-0.44$ year and $\mathrm{W} \infty=1737.9 \mathrm{~g}$. Growth performance index was calculated as $\varphi=3.09$ for length and $\varphi=1.69$ for weight. Mortality rates were $1.152 \mathrm{yr}^{-1}, 0.482 \mathrm{yr}^{-1}$ and $0.67 \mathrm{yr}^{-1}$ for total, natural and fishing mortality, respectively. The current exploitation rate (E) was 0.583 for both sexes combined.
\end{abstract}

\section{INTRODUCTION}

Bardawil lagoon is a large hypersaline coastal lagoon on the Mediterranean coast of Sinai, Egypt. Although it is shallow and oligotrophic (Touliabah et al., 2002), it is one of the most important lakes in Egypt as a source of good quality fish and a habitat for wildlife (Khalil and Shaltout, 2006; Mehanna, 2006a,b,c). The lagoon is considered the main ecological and economic natural resource in North Sinai region (Mehanna, 2006b; Mehanna, 2013; Mehanna et al., 2020).

The family Platycephalidae consists of approximately 80 species from 18 genera (Nelson et al., 2016). Platycephalus indicus, P. scaber and P. macracanthus are three famous species from the flathead family and the percentage of density of $P$. indicus is always high compared to others (Yeragi and Yeragi, 2014). This species has an important role in fisheries economy and it is a target species for capture in many places around the world (Parsamanesh et al., 2000). P. indicus is a benthic fish found on sandy beds in shallow areas, and opportunists carnivores (Yeragi and Yeragi, 2015). 
To estimate the biomass of different fish populations, it is necessary to know the length-weight relationships (LWRs) of the studied species (Mehanna and Farouk, 2021). The length-weight relationship is very crucial in estimating the standing stock biomass and discusses the development history of fish population from various regions (Petrakis and Stergiou, 1995). It is an important fishery management tool and it is very beneficial for cultivators and fisheries managers to determine the growth of the species (Nandikeswari et al., 2014b).

Age and growth is a vital component for understanding the ecology and life history of any fish species. It can be used to compare dynamics among water bodies, years, and fish sizes; describe trends over time; examine total mortality rates; and determine the general status of a population. Age is one parameter necessary to assess population dynamics and the state of exploited resources (Allain and Lorance, 2000).

Current work investigates age, growth and mortality of Platycephalus indicus in Bardawil lagoon. This work is the first attempt to study the age and growth as well as to estimate the mortality and exploitation rates of this species in Bardawil lagoon. This information is essential for future assessing the fishery status of this fish stock.

\section{MATERIALS AND METHODS}

\section{Study area}

Bardawil lagoon (Fig. 1) is one of the largest salt water lagoons in the northern coast of Sinai province of Egypt. It is one of the most important fishing grounds in Egypt, since it is the largest and almost free of pollution lagoon in Egypt (El-Bokhty and El-Aiatt, 2014). Bardawil lagoon is a natural depression and covers an area of $\approx 650 \mathrm{~km}^{2}$ with a depth of 0.3 to $3 \mathrm{~m}$ (EEAA, 2008).

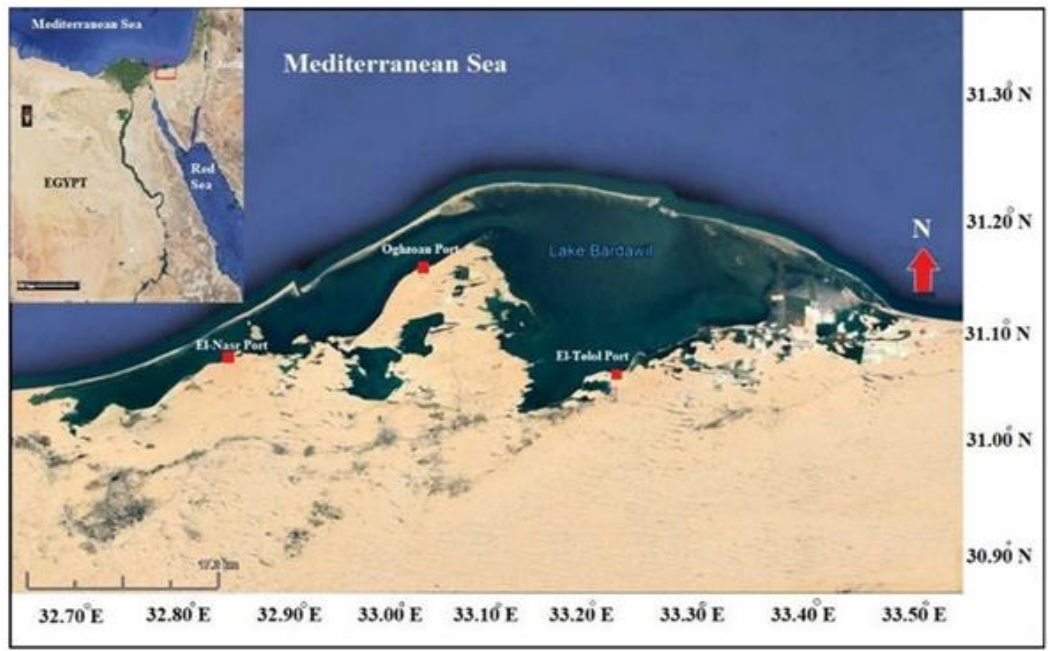

Fig. 1. A map of Bardawil lagoon.

\section{Sampling}

Monthly, random samples of bartail flathead (Platycephalus indicus) were collected from the mixed commercial catch of the main landing site at Bardawil lagoon. Total of 947 specimens of $P$. indicus varied from 17.9 to $52.1 \mathrm{~cm}$ total length with weights ranging between 27.6 and $1003.7 \mathrm{~g}$ were collected from August to December during two fishing seasons 2019-2020. The total length of P. indicus from the tip of the snout to the 
end of the caudal fin was measured to the nearest centimeter, total weight to the nearest 0.1 gram was recorded for each specimen. Otoliths were removed from 654 specimens for age determination.

\section{Methods}

\subsection{Age determination}

For age determination, 654 specimens as subsample were dissected and the otoliths were removed. In the present study, it was difficult to collect scales, since the scales of $P$. indicus are small and loosely embedded structures with hardly visible annual marks. Otoliths were cleaned by $8 \% \mathrm{HCl}$, and then dried. For reading, the otoliths were cleared in a mixture of 50\% ethyl alcohol and 50\% glycerin and they were examined using microscope.

\subsection{Total length - otolith radius relationship}

The relationship between total length and otolith radius was calculated for all fishes as follows: $\mathrm{L}=\mathrm{a}+\mathrm{b} \mathrm{S}$, where $\mathrm{L}$ is total length of fish in $\mathrm{cm} ; \mathrm{S}$ is the otolith radius in $\mathrm{mm}$; $\mathrm{a}$ and $\mathrm{b}$ the constant representing the intercept and the slope of the straight line respectively.

\subsection{Back-calculations}

Lengths by age were back-calculated using (Lee's, 1920) equation as follows: $\mathrm{L}_{\mathrm{n}}=$ $\mathrm{a}+\left(\mathrm{S}_{\mathrm{n}} / \mathrm{S}\right)^{*}\left(\mathrm{~L}_{\mathrm{c}}-\mathrm{a}\right)$, where $\mathrm{L}_{\mathrm{n}}=$ length of fish at age " $\mathrm{n}$ ", $\mathrm{S}_{\mathrm{n}}=$ the otolith radius to " $\mathrm{n}$ "annulus, $\mathrm{S}=$ total otolith radius, $\mathrm{L}_{\mathrm{c}}=$ fish length at capture and $\mathrm{a}$ is the intercept of the relation.

\subsection{Length-weight relationship}

The relation between the total length (L) and total weight (W) was computed using power equation as $\mathrm{W}=\mathrm{a} \mathrm{L}^{\mathrm{b}}$ (Le Cren, 1951), where: $\mathrm{a}$ and $\mathrm{b}$ are constants whose values were estimated by the least square method

\subsection{Von Bertalanffy growth parameters}

Theoretical growth in length and weight was obtained by fitting the von Bertalanffy growth model, using the (Ford, 1933; Walford, 1946) method. Von Bertalanffy (1949) for theoretical growth in length can be written in the form:

$\mathrm{Lt}=\mathrm{L} \infty\left[\left(1-\mathrm{e}^{-\mathrm{k}(\mathrm{t}-\mathrm{t} 0)}\right]\right.$

Where: $\mathrm{Lt}=$ the length at age $\mathrm{t}, \mathrm{L} \infty=$ the asymptotic length, $\mathrm{K}=$ growth coefficient and $\mathrm{t}_{0}$ $=$ age at which the length is theoretically nil.

\subsection{Growth performance index $(\varphi)$}

The growth performance index $(\varphi)$ for length was estimated as: $\varphi=\log K+2 \log$ L $\infty$ (Pauly and Munro, 1984), where: K and L $\infty$ are parameters of von Bertalanffy growth model).

\subsection{Mortality and exploitation rates}

The total mortality coefficient $(Z)$ was estimated using the linearized catch curve based on age composition data where $\mathrm{Z}=-\mathrm{b}$. The natural mortality coefficient $(\mathrm{M})$ was calculated by Hewitt and Hoenig formula (2005) as $M=4.22 / \mathrm{t}_{\max }$ where $\mathrm{t}_{\max }=3 / \mathrm{k}$, while the fishing mortality coefficient $(\mathrm{F})$ was calculated as $\mathrm{F}=\mathrm{Z}-\mathrm{M}$. Tee Exploitation rate $(\mathrm{E})$ was calculated after Gulland (1971) as $\mathrm{E}=\mathrm{F} / \mathrm{Z}$. 


\section{RESULTS AND DISCUSSION}

\section{Length-weight relationship}

The length-weight relationships can be used for forecasting both the potential yield and determining the most favorable size of capture to obtain optimum yield; these management parameters are directly related to the weight of the fish (Suresh et al., 2006). Length and weigh relationship in conjunction with age data can give information on the stock composite, age at maturity, life span, mortality, growth and production. The relative robustness or degree of well-being of a fish expressed as the coefficient of condition (condition factor) is an important tool for the study of fish biology, mainly when the species lies at the base of the higher food web (Diaz et al., 2000). The Length weight relationship is important for comparative growth studies (Moutopoulos and Stergiou, 2002; Mehanna and Farouk, 2021).

In the present study, the total length of the investigated species $P$. indicus was varied from 17.9 to $52.1 \mathrm{~cm}$ with weights ranging between 27.6 and $1003.7 \mathrm{~g}$. LWR of $P$. indicus (combined sexes) is presented in Fig. (2) and the equation derived from this relationship is as follows: $\mathrm{W}=0.002 \mathrm{~L}^{3.3402}\left(\mathrm{R}^{2}=0.98\right)$.

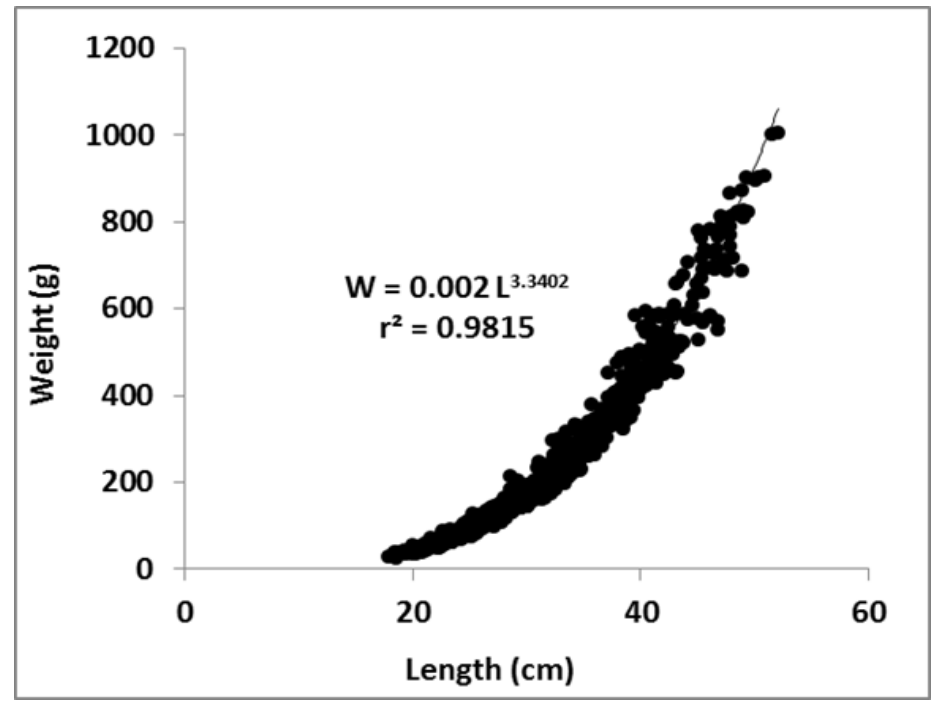

Fig. 2. Length-weight relationship of $P$. indicus $(+\overbrace{}^{\Uparrow})$ from Bardawil lagoon

The relationship equation showed a positive allometric where $b>3(b=3.3402)$. This result agrees with (Bawazeer, 1989; Alberto et al., 2003; Hashemi et al., 2012; Mohammadikia et al., 2012; Mohammadikia et al., 2013; Sabet, 2015; Adeleh et al., 2015; Samir and Akel, 2016; Akita and Tachihara, 2019; Hajializadeh et al., 2019). All these researchers found that, the value of (b) of bartail flathead $P$. indicus was positive allometric $(b>3)$ in different places. On the other hand, the $b$ value in this study was higher than that recorded by (Naik et al., 1990) where they found that, the values of (b) for the same species equals 2.99 for males and 2.91 for females in Indian waters, and also higher than that recorded by (King, 2007) in Queensland, Australia where the values of (b) was 3.

The variation of $b$ in the different regions could be due to the seasonal fluctuations in environmental parameters, physiological conditions of the fish at the time of collection, 
sex, gonad development and nutritive conditions in the environment of fish (Biswas, 1993; Mehanna and Farouk, 2021)

\section{Total length-otolith radius relationship}

The mean fish length and the average otolith radii per each length group are given in Table (1) and represented in Fig (3). The total length-otolith radius relationship is a straight line and expressed as: $\mathrm{Y}=-3.48+15.58 \mathrm{X}$ with $\mathrm{R}^{2}=0.95$.

Table 1. Fish frequency, mean length and mean otolith radii of $P$. indicus (sexes combined) collected from Bardawil lagoon during two fishing seasons 2019-2020

\begin{tabular}{|c|c|c|c|}
\hline \multirow[b]{2}{*}{ Length group (cm) } & \multicolumn{3}{|c|}{ Combined sex } \\
\hline & Frq. & $\begin{array}{c}\text { Mean } \\
\text { length cm }\end{array}$ & $\begin{array}{c}\text { Average } \\
\text { otolith } \\
\text { radius }\end{array}$ \\
\hline $17-17.9$ & 1 & 17.9 & 1.4 \\
\hline $18-18.9$ & 3 & 18.4 & 1.5 \\
\hline $19-19.9$ & 7 & 19.4 & 1.5 \\
\hline $20-20.9$ & 13 & 20.3 & 1.6 \\
\hline $21-21.9$ & 18 & 21.4 & 1.7 \\
\hline $22-22.9$ & 20 & 22.4 & 1.7 \\
\hline $23-23.9$ & 18 & 23.4 & 1.8 \\
\hline $24-24.9$ & 19 & 24.3 & 1.8 \\
\hline $25-25.9$ & 19 & 25.5 & 1.9 \\
\hline $26-26.9$ & 41 & 26.4 & 1.9 \\
\hline $27-27.9$ & 39 & 27.5 & 2.0 \\
\hline $28-28.9$ & 37 & 28.4 & 2.1 \\
\hline $29-29.9$ & 33 & 29.4 & 2.1 \\
\hline $30-30.9$ & 49 & 30.4 & 2.2 \\
\hline $31-31.9$ & 44 & 31.4 & 2.2 \\
\hline $32-32.9$ & 46 & 32.4 & 2.3 \\
\hline $33-33.9$ & 36 & 33.5 & 2.4 \\
\hline $34-34.9$ & 28 & 34.4 & 2.5 \\
\hline $35-35.9$ & 32 & 35.5 & 2.5 \\
\hline $36-36.9$ & 19 & 36.5 & 2.6 \\
\hline $37-37.9$ & 17 & 37.5 & 2.6 \\
\hline $38-38.9$ & 16 & 38.4 & 2.7 \\
\hline $39-39.9$ & 15 & 39.4 & 2.7 \\
\hline $40-40.9$ & 9 & 40.5 & 2.8 \\
\hline $41-41.9$ & 13 & 41.4 & 2.9 \\
\hline $42-42.9$ & 17 & 42.3 & 2.9 \\
\hline $43-43.9$ & 7 & 43.4 & 3.0 \\
\hline $44-44.9$ & 4 & 44.4 & 3.0 \\
\hline $45-45.9$ & 8 & 45.4 & 3.0 \\
\hline $46-46.9$ & 10 & 46.4 & 3.2 \\
\hline $47-47.9$ & 7 & 47.5 & 3.3 \\
\hline $48-48.9$ & 3 & 48.5 & 3.3 \\
\hline $49-49.9$ & 3 & 49.3 & 3.4 \\
\hline $50-50.9$ & 1 & 50.3 & 3.5 \\
\hline $51-51.9$ & 1 & 51.5 & 3.6 \\
\hline $52-52.9$ & 1 & 52.1 & 3.6 \\
\hline SUM & 654 & & \\
\hline
\end{tabular}




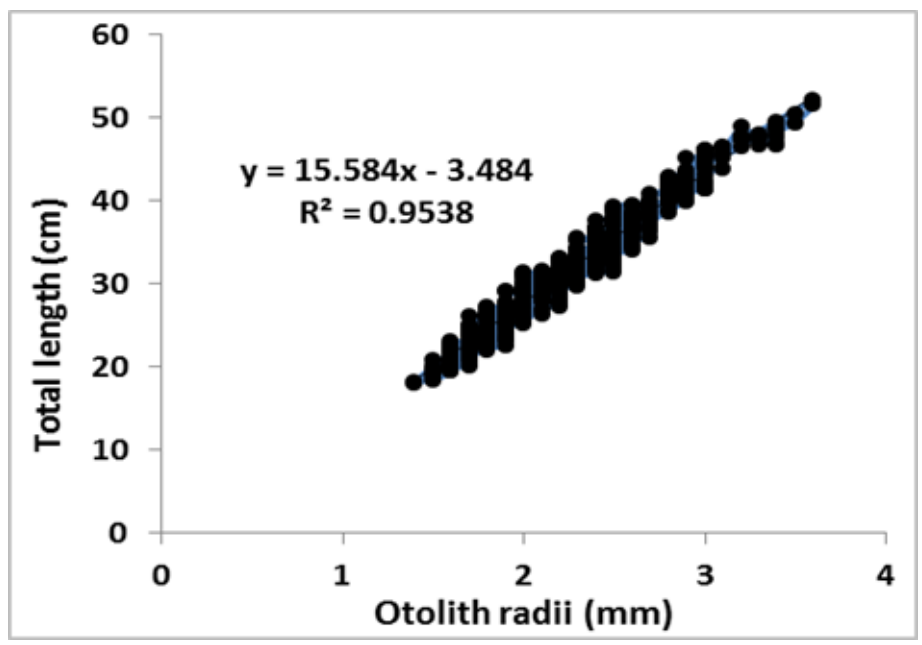

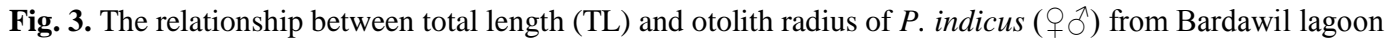

\section{Age composition}

The age composition of P. indicus in Bardawil lagoon during two seasons 2019 2020 was determined by counting the annual rings on otoliths of 654 specimens. Five age groups were observed with percentage of fishes of each age group are shown in Fig.(4). The results showed that age group I is the dominant age group in the catch contributing $35.3 \%$, while age group $\mathrm{V}$ was the lowest one in the catch of P. indicus in Bardawil lagoon. The present results compared with the previous ones are shown in Table (2). In this study, the results of age composition are lower than those reported by other authors, where all authors found more than five age groups for the same species in different places.

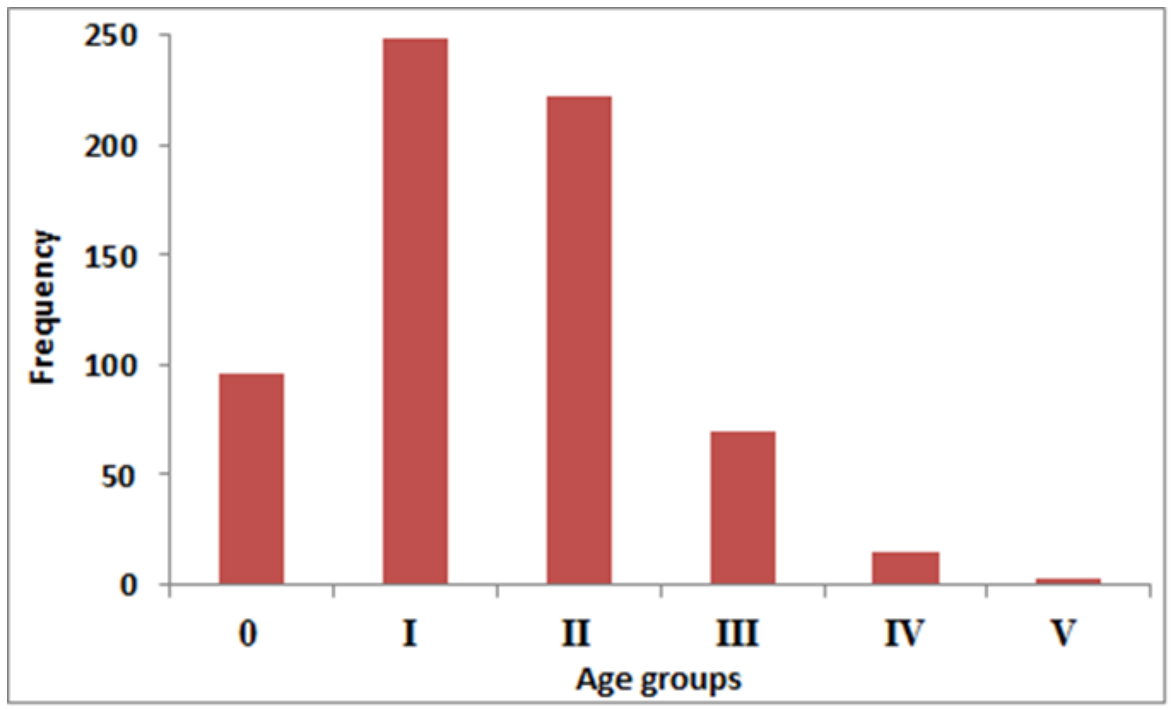

Fig. 4. Age composition of $P$. indicus (combined sexes) from Bardawil lagoon 
Table 2. The age composition of $P$. indicus recorded in previous and present studies.

\begin{tabular}{|c|c|c|c|c|}
\hline Region & $\operatorname{sex}$ & $\begin{array}{l}\text { Age estimation } \\
\text { method }\end{array}$ & $\begin{array}{l}\text { Maximum age } \\
\text { (Year) }\end{array}$ & Authors \\
\hline \multirow{2}{*}{$\begin{array}{c}\text { Persian Gulf in Kuwait } \\
\text { waters }\end{array}$} & 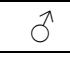 & \multirow{2}{*}{ otoliths method } & 6 & \multirow{2}{*}{ Bawazeer, 1989} \\
\hline & q & & 7 & \\
\hline \multirow{2}{*}{$\begin{array}{c}\text { Coastal waters off } \\
\text { west Kyushu, Japan }\end{array}$} & $\hat{0}$ & \multirow{2}{*}{ otoliths method } & 11 & \multirow[b]{2}{*}{ Masuda et al., 2000} \\
\hline & q & & 16 & \\
\hline \multirow{2}{*}{$\begin{array}{c}\text { Coastal waters of } \\
\text { Bandar Abbas }\end{array}$} & $0^{\pi}$ & \multirow{2}{*}{ otoliths method } & 4 & \multirow{2}{*}{$\begin{array}{c}\text { Mohammadikia et al., } \\
2013\end{array}$} \\
\hline & q & & 7 & \\
\hline \multirow{2}{*}{$\begin{array}{c}\text { Coastal waters of } \\
\text { Bandar Abbas }\end{array}$} & $0^{\pi}$ & \multirow{2}{*}{ otoliths method } & 4 & \multirow{2}{*}{$\begin{array}{c}\text { Mohammadikia et al. } \\
2014\end{array}$} \\
\hline & q & & 7 & \\
\hline \multirow{2}{*}{$\begin{array}{c}\text { The waters around } \\
\text { Okinawa-jima Island, } \\
\text { Japan }\end{array}$} & $0^{1}$ & \multirow{2}{*}{ otoliths method } & 7 & \multirow{2}{*}{$\begin{array}{c}\text { Akita and Tachihara, } \\
2019\end{array}$} \\
\hline & q & & 7 & \\
\hline Bardawil lagoon & $\lambda ㅇ$ & otoliths method & 5 & Present study \\
\hline
\end{tabular}

\section{Growth in length and weight}

The growth in length and growth increment of the different years of life are given in Figure (5). It is clear that the highest growth in length is occurred at the first year of life. The annual increment decreases with further increase in age. The average back calculated length of combined sexes are 23.4, 33.7, 41.5, 47.3 and $50.5 \mathrm{~cm}$ for ages $1^{\text {st }}$, $2^{\text {nd }}, 3^{\text {rd }}, 4^{\text {th }}$ and $5^{\text {th }}$ years of life, respectively. The highest increment occurred during the first year of life, while it decreases in the second year, reaching its minimal value during the fifth year of life.

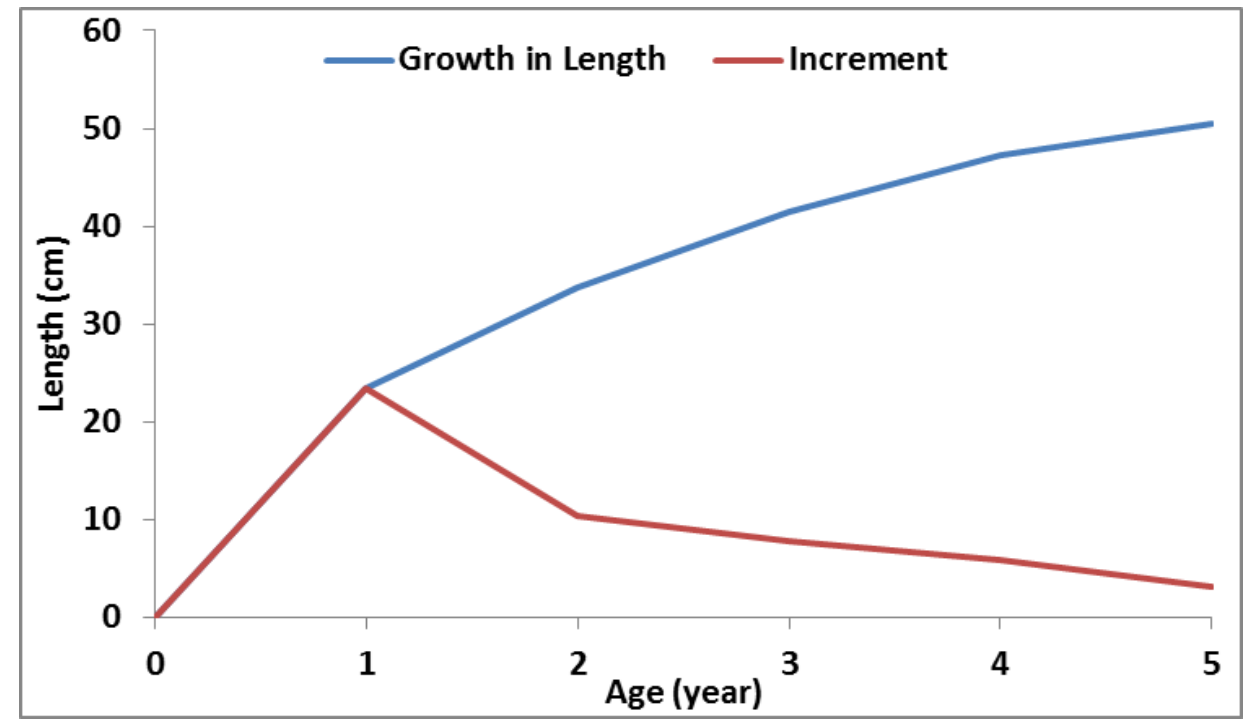

Fig. 5. Growth in length and annual increment of $P$. indicus $(+\overbrace{}^{\Uparrow})$ collected from Bardawil lagoon

The increasing in weight is very important than increasing in length for fishermen, where the landings are recorded as a weight. Calculated weights at the end of each year of life of $P$. indicus from Bardawil lagoon were estimated by applying the length-weight 
relationship. The calculated weights of combined sexes of $P$. indicus were 74.9, 253.29, $507.73,785.96$ and $978.06 \mathrm{~g}$ at the end of $1^{\text {st }}, 2^{\text {nd }}, 3^{\text {rd }}, 4^{\text {th }}$ and $5^{\text {th }}$ years of life, respectively.

Figure (6) shows the growth in weight and the annual increment for the sexes combined of $P$. indicus from Bardawil lagoon. The results showed that the weight increased successively and reached its maximum at age group IV.

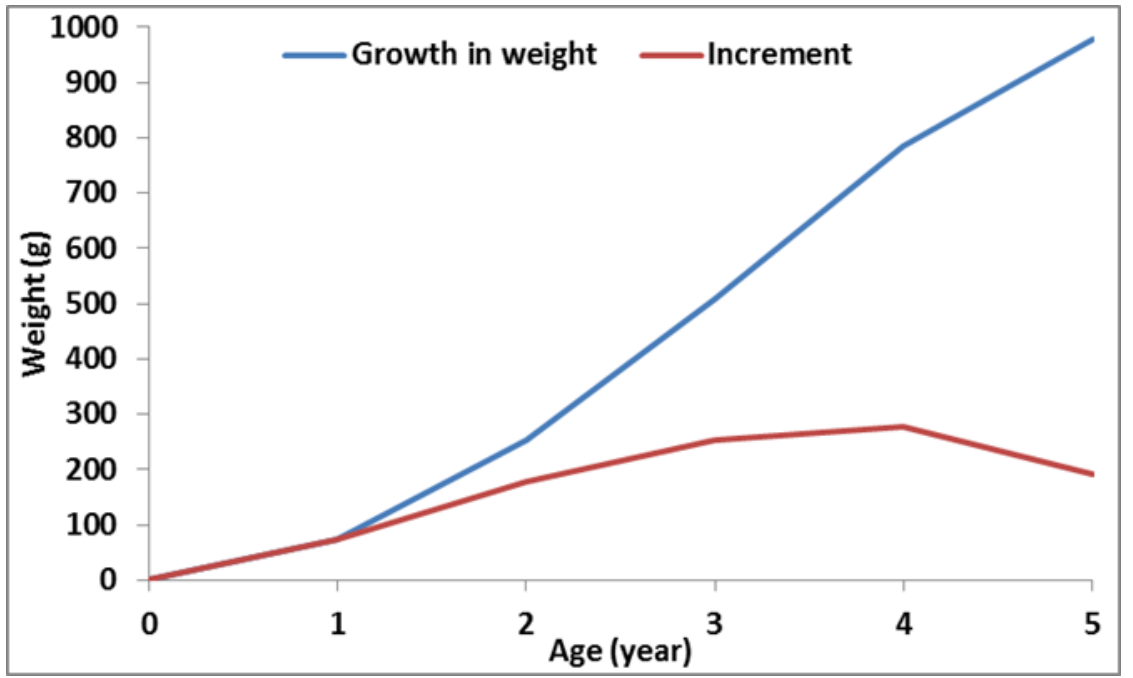

Fig. 6. Growth in weight and annual increment of P. indicus $(\stackrel{+}{\uparrow})$ from Bardawil lagoon.

\section{Growth parameters}

The von Bertalanffy growth parameters of bartail flathead ( $P$. indicus) were estimated as follow; $\mathrm{L} \infty=59.98 \mathrm{~cm}, \mathrm{~K}=0.34 \mathrm{yr}^{-1}, \mathrm{t}_{0}=-0.44$ year and $\mathrm{W} \infty=1737.92 \mathrm{~g}$. The von Bertalanffy equations for growth in length and in weight of $P$. indicus were estimated to be as follows:

$\mathrm{Lt}=59.98\left[\left(1-\mathrm{e}^{-0.34(\mathrm{t}+0.44)}\right]\right.$

$\mathrm{Wt}=1737.92\left[\left(1-\mathrm{e}^{-0.34(\mathrm{t}+0.44)}\right]^{3.3402}\right.$

Tirasin (1993) and Mcllwain et al. (2005) indicated that, growth parameters differed depending on species, population, age groups in the same population, maturity, sampling period for the same species and even sexes. So the differences observed in different locations may be accepted (Table 3).

Growth performance index $(\varphi)$ of the same species reflects its adaptations to the environment factors. The obtained results indicated that the growth performance index of $P$. indicus was 3.09 for length. The $\varphi$ in this study was higher than that estimated by (Bawazeer, 1989) in Kuwait waters where he found that, the $\varphi$ for the same species equals 2.91, and also $\varphi$ was higher than (Hashemi et al., 2014) in Iran, they found $\varphi$ equals 1.19. The $\varphi$ in this study was less than (Akita and Tachihara, 2019) in Japan where they found that, the $\varphi$ for the same species equals 3.26 (Table 3). Thus, it could be reported that the environmental condition of Bardawil lagoon is suitable for the growth of $P$. indicus under study. Such differences may be attributed partially to the different techniques used, but more likely reflect slight environmental differences such as food availability, Salinity and temperature (Pauly and Munro, 1984). 
Table 3. Growth parameters ( $\mathrm{L} \infty, \mathrm{K}$ and $\mathrm{t}_{0}$ ) and the growth performance index $(\varphi)$ for $P$. indicus in different localities

\begin{tabular}{|c|c|c|c|c|c|c|}
\hline Region & $\operatorname{sex}$ & $\mathrm{L}_{\infty}$ & $\mathrm{K}$ & $t_{0}$ & $\varphi$ & Authors \\
\hline \multirow{3}{*}{$\begin{array}{l}\text { Persian Gulf in } \\
\text { Kuwait waters }\end{array}$} & $0^{\pi}$ & 39.4 & 0.38 & -0.858 & 2.77 & \multirow{3}{*}{ Bawazeer, 1989} \\
\hline & q & 55 & 0.34 & -0.537 & 3.01 & \\
\hline & कृ & 48.9 & 0.34 & -0.64 & 2.91 & \\
\hline \multirow{2}{*}{ Japan } & $\hat{0}$ & 43.03 & 0.667 & -0.093 & 3.09 & \multirow{2}{*}{ Masuda et al.,2000 } \\
\hline & q & 55.15 & 0.478 & -0.125 & 3.16 & \\
\hline \multirow{2}{*}{ Persian Gulf, Iran } & $\hat{0}$ & 43.4 & 0.46 & -0.328 & 2.94 & \multirow{2}{*}{$\begin{array}{c}\text { Mohammadikia et al., } \\
2014\end{array}$} \\
\hline & q & 63 & 0.5 & -0.3 & 3.30 & \\
\hline \multirow{3}{*}{$\begin{array}{l}\text { Northwest of } \\
\text { Persian Gulf, Iran }\end{array}$} & $\hat{0}$ & 59 & 0.52 & -0.26 & 1.2 & \multirow{3}{*}{ Hashemi et al., 2014} \\
\hline & q & 64.14 & 0.36 & -0.37 & 0.91 & \\
\hline & $90^{\lambda}$ & 62.16 & 0.5 & -0.26 & 1.19 & \\
\hline \multirow{3}{*}{ Japan } & 0 & 53.6 & 0.68 & -0.379 & 3.29 & \multirow{3}{*}{$\begin{array}{c}\text { Akita and Tachihara, } \\
2019\end{array}$} \\
\hline & $q$ & 72.6 & 0.48 & -0.358 & 3.40 & \\
\hline & कृ & 67.52 & 0.4 & -0.76 & 3.26 & \\
\hline Bardawil lagoon & q & 59.98 & 0.34 & -0.44 & 3.09 & Present study \\
\hline
\end{tabular}

\section{Mortality and exploitation rates}

In the present study, total mortality $(\mathrm{Z})$ of $P$. indicus from Bardawil lagoon, Egypt was $1.15 \mathrm{yr}^{-1}$, natural mortality $(\mathrm{M})$ was $\mathrm{M}=0.48 \mathrm{yr}^{-1}$ and fishing mortality $(\mathrm{F})$ was 0.67 $\mathrm{yr}^{-1}$ for combined sexes. Also, the exploitation rate "E" of bartail flathead was calculated as 0.58 for both sexes.

The present $\mathrm{Z}$ and $\mathrm{M}$ values are lower than those obtained by (Hashemi et al., 2014) $\left(\mathrm{Z}=2.59, \mathrm{M}=0.77\right.$ and $\left.\mathrm{F}=1.28 \mathrm{yr}^{-1}\right)$ for the same species in Northwest of Persian Gulf, Iran and Mohammadikia et al. (2014) who estimated total mortality (Z) of $P$. indicus from the Persian Gulf, Iran as $1.62 \mathrm{yr}^{-1}$ for males and $1.43 \mathrm{yr}^{-1}$ for females, and estimated natural mortality $(\mathrm{M})$ as $\mathrm{M}=0.736 \mathrm{yr}^{-1}$ for males and $0.886 \mathrm{yr}^{-1}$ for females. Also, they calculated fishing mortality $(\mathrm{F})$ as 0.884 for males and 0.544 for females.

This difference can be explained by a very high fishing effort and a high natural mortality. Concerning mortality estimates, comparison is difficult because of scarcity of data and the total mortality coefficient is not a species-specific parameter, but an area specific parameter. These results could be explained by a high predation or other natural causes affecting fry and juveniles. Mortality parameters depend on both physiological factors (disease, old age, etc.), environmental factors (temperature, currents ...) (Christensen and Pauly, 1997).

The exploitation rate was estimated at 0.58 indicating that species still in healthy condition and working around the optimum exploitation.

\section{CONCLUSION}

In conclusion, this paper highlights the basic data on the age, growth, mortality and exploitation rates of Platycephalus indicus in Bardawil lagoon for the first time. Results give a full information which will be considered through the management of $P$. indicus in 
Bardawil lagoon. Results are still need further data analysis on reproductive biology, yield per recruit and recruitment pattern that may help in suggesting a management plan for such valuable fish. So, it is recommended to make a detailed study concerned gear selectivity, all biological and dynamical aspects as well as the catch and effort data to be make sure that the stock of $P$. indicus in Bardawil lagoon is exploited rationally.

\section{REFERENCES}

Adeleh, H.; Hakimeh, F. and Hamed M. (2015). Length-weight relationship of bartail flathead fish (Platycephalus indicus: Platycephalidae) in Bahrekan fishing area, Persian Gulf.

Akita, Y. and Tachihara, K. (2019). Age, growth, and maturity of the Indian flathead Platycephalus indicus in the waters around Okinawa- jima Island, Japan. published online, ISSN 1341-8998.

Alberto, S.; Velasco, F. and Olaso, L. (2003). Polychaetearmelids in the diet of demersal fish from the Southern shelf of the Bay of Biscay. The Marine Biological Association of the UK, Plymouth, UK, 83: 433-670.

Allain, V. and Lorance, P. (2000). Age estimation and growth of some deep sea fish from the northeast Atlantic ocean. Cybium, 24(3): 7-16.

Bawazeer, A. S. (1989). The stock and fishery biology of Indian flathead (wahar) Platycephalus indicus (Linnaeus), Family Platycephalidae in Kuwait waters. Kuwait Bulletin of Marine Science 10: 169-178.

Biswas, S. P. (1993). Manuel of methods in fish biology, fish biology \& Ecology laboratory, Dibruyarh University, Dibrugarh. $157 \mathrm{pp}$

Christensen, V. and Pauly, D. (1997). Placing fisheries resources in their ecosystem context. EC fisheries Cooperation Bull., 10(2):9-11.

Diaz, L. S.; Roa, A.; Garcia, C .B.; Acero, A. and Navas, G. (2000). Length-weight relationship of demersal fishes from the upper continental slope off Columbia. NAGA, 23(3): 23-25.

EEAA (Egyptian Environmental Affairs Agency) (2008). Egypt State of Environment Report. 356 pp.

El-Bokhty, E. B. and El-Aiatt, M. A. (2014). Trends in artisanal fisheries of Bardawil lagoon with reference to shrimp bottom trawling (kalsa). Egypt. J. Aquat. Biol. \& Fish., 18(4): 95 - 107.

Ford, E. (1933). An account of the herring investigation conducted at Plymouth. J. Marin. Biol. Ass. U.K., 19: 305 - 384.

Gulland, J. A. (1971). The fish resources of the Oceans. Fishing News Books Ltd., England. 255pp.

Hajializadeh, P.; Salahi, M.; Hashemi, S. H.; Kamrani, E. and Salarpouri, A. (2019). Length \& weight relationships of three fish species from Jask mangrove protected area in northern coastline of Gulf of Oman (Hormozgan, Iran): Liza klunzingeri (Day, 1888), Cociella crocodilus (Cuvier, 1829) and Platycephalus indicus (Linnaeus, 1758). J Appl Ichthyol; 35:1042-1043.

Hashemi, S. A.; Taghavimotlagh, S. A. and Arezoo V. (2014). Stock Assessment of Bartail Flathead (Platycephalus indicus Linnaeus, 1758) In Northwest of Persian Gulf, Iran. Journal of Fisheries Sciences.com. 8(2): 153-160. 
Hashemi, S. A.; Taghavimotlagh, S. A. and Eskandary, G. (2012). Some biological aspect of bartail flathead (Platycephalus indicus Linnaeus, 1758) in Northwest of Persian Gulf (Khuzestan Coastal Waters, Iran). World Journal of Fish and Marine Sciences 4 (2): 185-190.

Hewitt, D. A. and Hoenig, J. M. (2005). Comparison of two approaches for estimating natural mortality based on longevity. Fishery Bulletin 103: 433-437.

Khalil, M. T. and Shaltout, K. H. (2006). Lake Bardawil: Zaranik Protected Area. Publication of National Biodiversity Unit No. 15, Egyptian Environmental Affairs Agency (EEAA), Cairo, 599pp.

King, M. (2007). Fisheries biology \& assessment and management. Fishing news press, 340pp.

Le Cren, E. D. (1951). The length-weight relationship and seasonal cycle in gonad weight and condition in the Perch (Perca fluviatilis). J. Anim. Ecol., 20: 201-219.

Lee, R. (1920). A review of the methods of age and growth determination in fishes by means of scales. Fishery investigations, Series 2, Marine fisheries, Greet Britain Ministry of Agriculture, Fisheries and food 4 (2).

Masuda, Y.; Ozawa, T.; Onoueb, O. and Hamada, T. (2000). Age and growth of the flathead, Platycephalus indicus, from the coastal waters of west Kyushu, Japan. Fisheries Research 46: 113-121.

Mcllwain, J. L.; Claereboudt, M. R.; AL-Oufi, H. S.; Zaki, S. and Goddard, G. S. (2005). Spatial variation in age and growth of the Kingfish (Scomberomorus commerson) in the coastal waters of the Sultanate of Oman. Fish. Res., 73: 283 - 298.

Mehanna, S. F. (2006a). Lake Bardawil fisheries: current status and future sight. J. Egyp. Ger. Soc. Zool., 51(D): 91-105.

Mehanna, S. F. (2006b). Fisheries management of the thinlip grey mullet Liza ramada and golden grey mullet Liza aurata from Lake Bardawil, Egypt. Egyp. J. Aquat. Biol.\& Fish., 10 (2): 33-53.

Mehanna, S. F. (2006c). Fisheries regulations based on yield per recruit analysis for the spotted seabass Dicentrarchus punctatus (Moronidae) at Bardawil lagoon, Mediterranean coast of Sinai, Egypt. Egyp. J. Aquat. Biol. \& Fish., 10 (4): 129-145.

Mehanna, S. F. (2013). Sustainable development of Bardawil lagoon fisheries. First Regional Symposium on Sustainable Small-Scale Fisheries 27 - 30 November 2013, St. Julian's Malta.

Mehanna, S. F.; Eid, A. S.; Ali, B. A. and Aabed, M. S. (2020). Fishing gears, catch composition and length at first capture of the common fish species in Bardawil lagoon, Egypt. Egyptian Journal of Aquatic Biology \& Fisheries, 24(5): 523 - 538.

Mehanna, S. F. and Farouk, A. (2021). Length weight relationship of 60 fish species from species from the eastern Mediterranean Sea, Egypt (GFCM-GSA 26) Front. Mar. Sci. doi: 10.3389/fmars.2021.625422

Mohammadikia, D.; Kamrani, E.; Taherizadeh, M. R.; Saghar, N. (2013). A comparison study on some biological aspects of Platycephalus indicus in coastal waters of Bandar Abbas.J. Aqu. Eco., 2(3): 56-41.

Mohammadikia, D.; Kamrani, E. and Taherizadeh, M. R. (2014). Age and growth of flathead, Platycephalus indicus from the Persian Gulf (Bandar Abbas, Iran). Journal of the Marine Biological Association of the United Kingdom 94:1063-1071. 
Mohammadikia, D.; Kamrani, E.; Taherizadeh, M. R.; Saghar, N.; Dehghani, R. and Dabbagh, A. R. (2012). Platycephlidae (Vertebrates; Fish) of Bandar Abbas Waters (Persian Gulf, Iran). Journal of Animal Science Advances, 2(5): 429- 432.

Moutopoulos, D. K. and Stergiou, K. I. (2002). Length-weight and length-length relationships of fish species from Aegean Sea (Greece). Appl. Ichthyol. 18: 200-203.

Naik, S. K.; Shanbhogue, S. L.; Jayabalan, N. and Krishna-Bhat, C. (1990). Observations on Platycephalus indicus from the NetravatiGurpur Estuary, Mangalore. Environ. Ecol., 8(4): 1311-1313.

Nandikeswari, R.; Sambasivam, M. and Anandan, V. (2014). Length-weight relationship of Terapon jarbua (Forsskal, 1775) from Puducherry waters. Int. J. Biol. Biomol. Agric. Food Biotechnol., 8(3): 277-281.

Nelson, J. S.; Grande, T. C. and Wilson, M. V. H. (2016). Fishes of the world (Fifth edition). John Wiley \& Sons.

Parsamanesh, A.; Kashi, M. T. and Eskandari, G. H. (2000). Stock Assessment of Commercial Fish in Coastal Waters of Khuzestan Province. Fishery Research Institute, 70pp.

Pauly, D. and Munro, J. L. (1984). Once more on the comparison of growth in fish and invertebrates. ICLARM Fishbyte, 2 (1): 21.

Petrakis, O. and Stergiou, K. I. (1995). Weight-length relationships for 33 fish species in Greek waters. Fish. Res., 21: 465-469.

Sabet, H. M.; Heidari, A. and Fekrandish, H. (2015). Population structure, length-weight and length-length relationships of six populations of the Bartail Flathead Platycephalus indicus (Scorpaeniformes: Platycephalidae) along the Persian Gulf coastal waters. Journal of Threatened Taxa, 7(1): 6810-6814.

Samir, I. R. and Akel, E. H. (2016). A contribution to Biometric Analysis and Lengthweight relationship of Platycephalus indicus (Linnaeus, 1758) obtained off Port Said (Egyptian Mediterranean waters). Acta Velit 3(1), ISSN: 2394-3092.

Suresh, V. R.; Biswas, B. K.; Vinci, G. K.; Mitra, K.; Mukherjee, A. (2006). Biology and Fishery of Bared Spiny eel, Macrognathus pancalus Hamilton. Actaichthyologica et Piscatoria 36 (1): 31-37.

Tirasin, M. (1993). The studies on growth parameters of fish population (in Turkish), The Scientific and Technical Research Council of Turkey, Journal of Zoology, C. 29: 2982.

Touliabah, H.; Safik, H.; Gab-Allah, M. and Taylor, W. (2002). Phytoplankton and some abiotic features of El-Bardawil Lake, Sinai, Egypt. Afr. J. Aquat. Sci. 27: 97-105.

Walford, L. A. (1946). A new graphic method of describing the growth of animals. Mar. Biol. Bull. 90 (2): $141-147$.

Yeragi, S. S. and Yeragi, S. G. (2014). Food and feeding habit of Mystus seenghala (syks) the common catfish of Mithbav estuary of south konkan, Sindhudurg district, Maharashtra, India. Int. Res. J. of Science and Enginnering, 2(2).

Yeragi, S. S. and Yeragi, S. G. (2015). Food and feeding habit of Bartail Platycephalus indicus (Linnaeus, 1758) In Mithbav Creek of South Konkan, Maharashtra, India. J. Adv. Zool., 36(2) : 79-82. 